Article

\title{
First They Came for the Poor: Surveillance of Welfare Recipients as an Uncontested Practice
}

\author{
Nathalie Maréchal \\ School of Communication, University of Southern California, Los Angeles, CA 90007, USA; E-Mail: marechal@usc.edu \\ Submitted: 8 April 2015 | In Revised Form: 15 July 2015 | Accepted: 4 August 2015 | \\ Published: 20 October 2015
}

\begin{abstract}
There have been moments in American history when government surveillance of everyday citizens has aroused public concerns, most recently Edward Snowden's 2013 revelations concerning widespread, warrantless surveillance of Americans and foreigners alike. What does not arouse public concern are longstanding governmental practices that involve surveillance of poor people who receive certain types of public benefits. This article traces the political history of U.S. poverty-relief programs, considers the perspective of welfare beneficiaries themselves, analyzes American cultural beliefs about the poor in order to offer some thoughts on why those surveillance practices garner little public concern, and argues that those who are concerned about warrantless surveillance of ordinary citizens should do more to protect ordinary poor citizens from surveillance.
\end{abstract}

\section{Keywords}

beneficiaries; poor; poverty; public benefits; surveillance; welfare

\section{Issue}

This article is part of the special issue "Surveillance: Critical Analysis and Current Challenges", edited by James Schwoch (Northwestern University, USA), John Laprise (Independent Researcher) and Ivory Mills (Northwestern University, USA).

(C) 2015 by the author; licensee Cogitatio (Lisbon, Portugal). This article is licensed under a Creative Commons Attribution 4.0 International License (CC BY).

\section{Introduction}

There have been moments in American history when government surveillance of everyday citizens has aroused media attention. These moments include Edward Snowden's revelation of NSA practices in 2013, the 1972 media revelations of $\mathrm{FBI}$ widespread surveillance of United States citizens, and perhaps even the Joseph McCarthy hearings in 1954. What does not arouse public concern are longstanding governmental practices that involve surveillance of poor people who receive certain types of public benefits. This article outlines some of those surveillance practices, offers some thoughts on why those surveillance practices garner little public concern, and argues that those who are concerned about warrantless surveillance of ordinary citizens should do more to protect ordinary poor citizens from surveillance.

Since Edward Snowden's first revelations in July 2013, Americans-and the world-have learned that millions of individuals are under surveillance by the U.S. national security apparatus. The controversy surrounding these practices is typically framed in terms of trade-offs between civil rights and liberties (including privacy) on the one hand, and national security concerns on the other. These national security concerns almost invariably invoke the specter of the 9/11 terrorist attacks. However, the trend toward increased surveillance predates $9 / 11$. Notably, federal national security and law enforcement agencies systematically infiltrated and spied on African American communities, civil rights activists and anti-war groups throughout the 1950s, 1960s and early 1970s under the COINTELPRO program (Glick, 1989). The specific targets of state surveillance vary, but the logic stays the same: surveil, control and isolate the sources of perceived risk in order to prevent contagion to the rest of society (Beck, 1992). Since 9/11, Arab and Muslim communities have been the prime targets of domestic surveillance (Greenwald \& Hussain, 2014), and several recent books 
have examined the Internet economy's reliance on commodification of myriad data points concerning citizen-consumers, gradually habituating us all to pervasive surveillance (Angwin, 2014; Scheer, 2015).

One group of individuals who have been consistently surveilled for decades is generally left out of this conversation: the poor. Indeed, low-income Americans must submit to invasive monitoring of their private lives in order to receive the benefits to which they are legally entitled. This has been the case for decades, with the breadth and depth of surveillance expanding along with the affordances of available technologies. In contrast, very little documentation is required to receive benefits in the form of tax rebates, which generally benefit the rich and amount to much higher sums. Moreover, this mass invasion of privacy receives broad support from the American public, including from many recipients themselves, who often have only vague ideas of what the computerized welfare system knows about them or how this information is acquired (Gustafson, 2011).

Thus, one of the features of 21st century American welfare is widespread surveillance that is poorly understood by its subjects - and, I will argue, whose subjects are largely invisible to mainstream American society. In this paper I use John Gilliom's definition of surveillance: "the increasingly routine use of personal data and systematic information in the administration of institutions, agencies, and businesses" (Gilliom, 2001, p. 2 ). As we have learned since 2013, mass surveillance has become a hallmark of 21st century American life. Writing in The New Prospect, SUNY professor Virginia Eubanks warns that "the revelations that are so scandalous to the middle class-data profiling, PRISM, tapped cell phones-are old news to millions of lowincome Americans, immigrants, and communities of color." She recounts an interview with a young mother on welfare, who told her that while receiving her food stamps though Electronic Bank Transfer (EBT) was convenient, her case worker used the system to review her grocery purchases item by item. "Poor women are the test subjects for surveillance technology," the young woman told Eubanks, "and you should pay attention to what happens to us. You're next." This conversation occurred a decade ago (Eubanks, 2014, para 2).

This article analyzes the cultural norms and beliefs embodied by the American welfare system, considers these norms and beliefs' involvement in other aspects of the surveillance society, critiques the current regime of welfare data collection, and calls for an administration of the social safety net that is both more humane and more effective. After providing an overview of the history of the American social safety net as it stands, emphasizing Johnson's War on Poverty and the Clinton welfare reform, I will turn to the perspectives of welfare recipients themselves and of the general American public, before finally suggesting some directions for future research and policy action.

\section{The American Welfare State}

The phrase "welfare state" refers to a normative view of government that holds the public sector ultimately responsible for the physical, social and economic wellbeing of the citizenry. While European countries began providing state-run and tax-funded social safety nets and labor protections starting in the late 19th century, in the U.S. the prevailing view of the elites was that assistance to the needy would only encourage idleness and other undesirable behavior, and that social Darwinism would ensure that only the individuals with the best work ethic and moral character would prosper and reproduce. Franklin Delanoe Roosevelt's New Deal, in the wake of the Great Depression, represented a departure from the past through programs such as the Works Progress Administration, later renamed the Works Projects Administration (WPA), which created employment through great works projects; Social Security, a retirement program for old age and the disabled; and many other poverty-relief programs collectively referred to as "welfare" (O'Connor, 2003).

In addition to Social Security, intended to care for those relatively few (compared to today) individuals who made it to old age, New Deal welfare programs were designed to replace the earnings of an absent, deceased or otherwise incapacitated father figure, thereby allowing mothers to continue in their roles as home-makers and primary care-givers for their children. It is important to note that women of color were largely excluded from receiving benefits through both structural and individual-level racism on the part of program administrators (Mink, 1996; Neubeck \& Cazenave, 2001; O'Connor, 2003; Quadagno, 1994).

Decades later, Lyndon Johnson's Great Society, which included both the War on Poverty and civil rights legislation, went a long way toward easing the structural barriers preventing poor blacks from receiving aid as well as institutionalizing the welfare system. However, as black Americans fought to access welfare programs (Piven \& Cloward, 1979), public perception of the average welfare recipient shifted from the virtuous white widow heroically raising her children alone to the lazy, promiscuous, deviant (and wholly imaginary) black "welfare queen" mythologized by Ronald Reagan (Gilliom, 2001; Gustafson, 2011; O'Connor, 2003).

The welfare assistance program was further expanded in the 1960s as part of Lyndon Johnson's Great Society initiative, intended to eradicate poverty and correct structural racial injustice. The War on Poverty was thus intertwined with government efforts to enact the demands of the civil rights movement. A comprehensive policy analysis of the War on Poverty would fall outside the scope of the present paper; however a few key facts merit foregrounding. The 1965 Social Security Act raised benefits, increased eligibility, created Medicare (federally-funded medical insurance for Americans 
over age 65) and Medicaid (medical insurance for lowincome Americans, jointly funded by the federal and state governments), while the 1964 Food Stamp Act made the program permanent (it had consisted of pilot programs until then). Other legislation created the school lunch program, through which poor children receive meals through their schools, and even provided contraception for poor adults through state health departments. By the end of the Johnson Administration, the U.S. appeared to be on its way to easing, if not eradicating, poverty (O'Connor, 2003).

Even as surveillance, work requirements and fraud prevention programs continued to grow, the 1970s, 1980s and early 1990s saw two broad social changes that would prove crucial to the welfare system: changes to the family structure and demographic composition of welfare rolls, and technological advances in information management (Gilliom, 2001; O'Connor, 2003). Divorce and single parenthood became more prevalent, some of the structural barriers preventing poor people of color from accessing aid were dismantled, and the availability of birth control made single motherhood seem more and more like a choice, and less like an unavoidable tragedy. As a result, the American public (and legislators) became less willing to provide support to the poor, and especially to poor, black, single mothers who were increasingly stigmatized as lazy, promiscuous and undeserving. The "welfare queen" rhetoric espoused by Reagan and others also contributed to increased prejudice and stigmatization of poor Americans (Hancock, 2004; Gilens, 1999; Gustafson, 2011; O'Connor, 2003). Writing in 1982, M. Donna Price Cofer warned that "the current mania in this country to dismantle thirty years of social programs will adversely affect not only public assistance recipients but also the agencies that administer these benefits" (Cofer, 1982).

At the same time, networked databases made it possible to classify and surveil large populations, and to do so across administrative boundaries of city, county and state human services offices. To be sure, no welfare state could function without some degree of administrative surveillance. Frank Webster (2014) summarizes the intertwined nature of publicly administered benefits and some degree of surveillance succinctly, reminding us of Anthony Giddens' (1987) assertion that "the administrative power generated by the nation-state could not exist without the information base that is the means of its reflexive selfregulation" (p. 180), and of Paddy Hillyard and Janie Percy-Smith's (1988) conclusion that "the delivery of welfare benefits and services is at the heart of the system of mass surveillance, because it is here that the processes of classification, information gathering and recording are constantly multiplying" (p. 172) (cited in Webster, 2014, p. 298-299).

The combination of increased motivation to reduce welfare spending and increased technical ability to monitor welfare recipients could only lead to increased surveillance, and Cofer's fears would be realized as part of a deal between Bill Clinton and the Gingrich Republicans in the run-up to the 1996 election (O'Connor, 2003).

The 1996 welfare reform bill, formally (and tellingly) titled the Personal Responsibility and Work Opportunity Reconciliation Act (PRWORA), was the culmination of two decades of "conservative ideological and political victories" (O'Connor, 2003, p. 223). As such, it was more concerned with sending a message to the poor about personal morality than about designing evidence-based interventions to provide Americans with a basic minimum standard of living, much less durably lifting families out of poverty. As O'Connor notes, "the preamble to the PRWORA openly describes it as being principally concerned with overcoming the problems caused by out-of-wedlock births and welfare dependency. Further, the act claims that its purpose is to strengthen marriage, personal responsibility, and the work ethic" (O'Connor, 2003, p. 224). Actually reducing poverty is nowhere on the agenda.

The Clinton welfare reform was based on the premise that nearly all parents should work outside the home to support their children, even if the wages they could command in the labor market were less than the cost of childcare. By the 1990s, women's participation in the workforce was already well-entrenched, and the idea that welfare ought to provide an income to poor, husbandless mothers, so that they might stay at home raising their children, was at odds with the new norm of dual-income families. For many, the difficulties of raising children alone while working outside the home were simply the natural consequence of the "irresponsible choice" to have children without a husband's practical and financial support. As we will see, restricting poor women's options with respect to their sexual and reproductive lives-arguably the most personal, private realms of human existence-is a feature, not a bug, of the American welfare system.

The welfare-to-work program featured a number of "sticks and carrots" intended to incentivize work and discourage fraud (or so the claim went), but in practice, the rules were (and continue to be) poorly understood, haphazardly applied, and, it seems, arbitrarily enforced (Gustafson, 2011; Hasenfeld, 2000; Schram, 2000). Moreover, benefit levels are woefully inadequate ${ }^{1}$, and

\footnotetext{
${ }^{1}$ Any good faith discussion of welfare fraud must begin by acknowledging the inadequacy of benefits. To use California as an example, as of 2011, the minimum basic standard of adequate care, as determined by the federal government, for a family of three was $\$ 1,135$ per month. The Maximum Income for Initial Eligibility for a Family of Three was \$1,224, meaning that families earning more than that amount are ineligible for aid. Families needed to already be significantly below the poverty line before they could even apply for aid. The asset limit was $\$ 2,000(\$ 3,000$ for households including an elderly per-
} 
families must resort to alternative sources of income to make ends meet. The result is both endemic fraud and widespread underutilization of benefits to which individuals and families are legally entitled (Gustafson, 2011).

The 1996 Act set time limits on how long individuals could receive benefits, imposed work requirements, and drastically tightened eligibility rules. The federallyrun Assistance for Families with Dependent Children (AFDC) was replaced by Temporary Assistance for Needy Families (TANF), which is implemented by the states. Under PRWORA the states are given clear incentives from the federal government to "get as many of their welfare population working as possible" (O'Connor, 2003 , p. 230). States are also free to impose even tighter eligibility rules and shorter time limits than those envisioned by the PRWORA. The guiding principle of TANF is not meeting the basic needs of poor Americans, but "fraud prevention" (Gustafson, 2011, p. 96).

The Act also empowered state governments to delve into the personal and sexual lives of women of all ages, by requiring single mothers to identify the biological fathers of their offspring and by capping TANF payments to families, meaning that "recipients do not receive any further money if they have more children while on the TANF program" (O'Connor, 2003, p. 230). These "family size caps" are meant to dissuade women from having additional children while on welfare by barring newly born children from being included in benefit calculations. The implication is that the only "legitimate" children are those born to a married mother and father, and that, by definition, the child of a mother on welfare is not "legitimate." During the PRWORA negotiations, "much of the debate cast 'illegitimacy' as America's most pressing social problem, and quickly blamed 'welfare' as its root cause" (O'Connor, 2003, p.235).

While the Act's authors preferred co-parents to be married to each other, in the absence of marriage they were determined to more strictly enforce child support requirements. The implementation of a "national computer tracking system" made it easier to "locate nonresident parents across state boundaries" and garnish their wages (O'Connor, 2003, p. 232). Mothers who can't or won't identify their children's biological father risk losing their TANF eligibility. Money recouped from so-called "dead-beat dads" goes not to the children or their mother, but to the state as a reimbursement for

son), plus one automobile per licensed driver-requiring families to have sold off virtually all their assets. The Maximum Monthly Benefit for a Family of Three with No Income was $\$ 638$ (non-exempt) or \$714 (exempt)-slightly more than half of what the government considers necessary for survival. By contrast, the MIT Living Wage Calculator project estimates that such a family needs $\$ 54,764$ per year, or $\$ 4,564$ per month, to make ends meet in California (Glasmeier \& Schulteis, 2015). the cost of support that the father should have been providing in the first place, with the exception of a $\$ 50$ pass-through (O'Connor, 2003). Mothers thus have every economic incentive to resist identifying their children's father.

States also "have the discretion to deny benefits to unmarried teenage mothers," "can mandate teenage mothers attend school," and "require unwed minors to live with a parent or guardian" to receive aid (O'Connor, 2003, p. 230)-regardless of whether that is in the best interest of the young mother or her child. Meanwhile, "the act required the federal government to spend $\$ 50$ million per year on a new abstinence education program in American schools" (O'Connor, 2003, p. 231) and provided "financial rewards to states that reduce the number of out-of-wedlock births as long as there is not a corresponding increase in the number of abortions performed in that state" though these "illegitimacy bonuses" were short-lived (O'Connor, 2003, p.231). For all the emphasis on preventing child-bearing by unmarried poor women, PRWORA did nothing to promote use or affordability of methods of birth control other than sexual abstinence. The real problem that PRWORA sought to eradicate wasn't child poverty or even fatherlessness, but sexual activity by poor women (and especially poor women of color) outside the bounds of holy matrimony.

\section{Welfare Surveillance: The Recipients' Perspective}

According to John Gilliom (2001), "high levels of investigation into the lives of the poor have always been a central part of relief programs" in the United States, "generally designed with little attention to the dignity of the client" (pp. 13-14). This surveillance focuses on "whether or not a family will be eligible for assistance," which is accomplished through a "means test" consisting of "some mechanism for determining if someone is eligible by assessing their needs, their resources, or their capacity to work." For Gilliom, "this one constant in American welfare surveillance, reflecting both our faith in the importance of labor and our suspicion that people will do nearly anything to avoid it, is the central point in the ongoing state examination of the poor" (Gilliom, pp. 19-20).

Ethnographic work by Gilliom (2001), Gustafson (2011), Seccombe (2011), and others provides rich insight into the ways that welfare recipients experience their interactions with the state's surveillance system. Gilliom writes:

Low-income American mothers live every day with the advanced surveillance capacity of the modern welfare state. In their pursuit of food, health care, and shelter for their families, they are watched, analyzed, assessed, monitored, checked, and reevaluated in an ongoing process involving supercomput- 
ers, caseworkers, fraud control agents, grocers, and neighbors. (Gilliom, 2001, p. xiii)

Additionally, the burden of complying with eligibility verification requirements is often so time-consuming that it interferes with recipients' ability to look for work or care for their families. In rural areas with scant public transportation options, a visit to deliver paperwork to the welfare office can take an entire day. Electronic submission of required documents is either disallowed by the welfare agency, or unavailable to recipients who lack the necessary hardware, Internet access, and computer skills. To add insult to injury, many offices require the same paperwork to be resubmitted on a recurring basis, even though the documentation (Social Security cards, children's birth certificates) does not change over time. As Gustafson notes,

The documentation of daily life is a form of state surveillance to which welfare recipients submit but also a form of surveillance which they resist, sometimes to their detriment. It was this routine documentation that the interviewees described as invasive and oppressive (Gustafson, 2011, p. 97).

Gilliom's field work also revealed that "the mothers complained about the hassle and degradation caused by surveillance and the ways that it hindered their ability to meet the needs of their families" (Gilliom, 2001, p. 6). Time spent traveling to the welfare office is often perceived as time wasted, and means tests dissuade recipients from taking part-time work or work that would pay less than their welfare benefit-unless they can hide this income from the eligibility worker. Gilliom and Gustafson both describe the calculations that mothers in particular engage in before rationally concluding that their duties to their children demand that they engage in welfare fraud, whether by working under the table or claiming not to know the father's identity or his whereabouts-even if he is in fact a part of the children's lives. Thus, "as the state struggles to know as much as it can about the poor-and to use its knowledge with critical consequences for poor people's lives-an inevitable struggle over information and perception comes to define the unfolding politics of surveillance" (Gilliom, 2001, p. 20).

As with other populations under similar surveillance, welfare recipients feel the psychic weight of living their lives under the watchful eye of the State. The following quotation exemplifies the psychological effect of pervasive surveillance:

You have to watch every step like you are in prison. All the time you are on welfare, yeah, you are in prison. Someone is watching like a guard. Someone is watching over you and you are hoping every day that you won't go up the creek, so to speak, and (that you will) get out alive in any way, shape or form. You know, "Did I remember to say that a child moved in?" "Did I remember to say that a child moved out?" And, "Did I call within that five days?" You know...making sure all the time.....It's as close to a prison that I can think of. (Mary, a fortysomething mother of three, on welfare, in Appalachian Ohio (cited in Gilliom, 2001, p. 1))

Paradoxically, Gustafon's field work "revealed that while these welfare recipients found it impossible to comply with the rules and most considered it impossible for anyone to follow the rules, many of the interviewees nonetheless believed that the work requirements, the time limits, the family caps, the extensive reporting rules, and the stiff penalties for breaking the rules were good, necessary, and legitimate" (Gustafson, 2011, p. 170). The women interviewed by both Gilliom and Gustafson had internalized the widespread cultural prejudice against people living in poverty, often buying into tropes that had no basis in reality, such as the Welfare Queen invented by Ronald Reagan. In both studies, virtually all respondents shared the attitude that while they themselves needed and deserved the social safety net, most other people on aid were abusing the system-a perception that is sadly prevalent. The next section delves into the cultural norms and beliefs held by mainstream American society about the poor in general, and welfare recipients in particular.

\section{Welfare Surveillance: The "Taxpayers"” Perspective}

The following quote, from the online comments on Virginia Eubanks' article in The New Prospect, illustrates the widespread belief that welfare payments belong not to the recipient, but to the taxpayer: "As a taxpayer I applaud looking at EBT records to see if you are spending MY money on WHAT I approve of, as in MY money" (online comment to Eubanks, 2014). This line of argumentation suggests an opposition between taxpayers and welfare recipients, between working Americans and poor Americans (even though these conditions are hardly mutual exclusive), in a telling throwback to the 18th and early 19th centuries, when only landowners-who were, of course, exclusively white and male, and didn't necessarily work themselves-could vote. Nearly 200 years later, arguments that full participation in society is tied to economic participation through tax-paying remain, framing the right to vote as the province of the "productive," and not as an inherent right conferred by citizenship. Dorothy E. Roberts characterized this divide as one between citizens and subjects (Roberts, 1996). This conception, of course, obscures the fact that no one is a tax payer throughout the life cycle (childhood, old age), and there are very few people who never pay taxes. We can see this wealth-based model of citizenship at work 
in present-day efforts to pass voter ID requirements, which overwhelmingly impact the poor, and to the drastically different rhetoric surrounding taking advantage of tax deductions, which disproportionately benefit the wealthy and upper-middle classes.

This frame was prominent during Mitt Romney's 2012 presidential campaign, especially after Romney was recorded telling a room of wealthy campaign donors that "47 per cent" of Americans were "moochers" who "paid no income tax" and didn't take "personal responsibility...for their lives" (Beutler, 2014). Romney's running mate Paul Ryan similarly contrasted "makers" to "takers," and a number of political commentators have noted that this was a "foundational belief" of the Romney/Ryan campaign (Beutler, 2014, para 8). In contract, Barack Obama, who was then running for reelection, was quick to retort:

When you express an attitude that half the country considers itself victims, that somehow they want to be dependent on government...maybe you haven't gotten around a lot...the American people are the hardest-working people there are. Their problem is not that they're not working hard enough or that they don't want to work, or they're being taxed too little, or that they just want to loaf around and gather government checks. People want a hand up, not a handout" (quoted in Landler, 2012).

The claim that entitlement spending was out of control and unaffordable for the federal budget reemerged in late 2013 as Congress debated whether to authorize an extension of unemployment benefits for the millions of Americans who lost their jobs during the Great Recession and whose unemployment insurance was about to expire. Yet even the strongest advocates of extending unemployment insurance, such as the office of Harry Reid, then the Senate Majority Leader, differentiated between the deserving unemployed who had fallen victims to the recession "through no fault of their own" and "need this lifeline to make ends meet while they continue to look for work" (Kaplan, n.d.), and the undeserving, unmentioned masses of the poor dependent on other forms of public assistance.

While Democrats, liberals and progressives essentially remain quiet about welfare recipients, Republicans and other conservatives are quite vocal about their beliefs that poverty is primarily the individual's fault, and that poverty relief hurts rather than helps the poor. For example, a Forbes article by Peter Ferrara claims that the War on Poverty caused poverty rates to rise after 1965, while simultaneously asserting that "one major reason that poverty stopped declining after the War on Poverty started is that the poor and lower income population stopped working" (Ferrara, 2013, para 7), and foregrounding the War on Poverty's "association with the breakup of lower-income families and soaring out-of-wedlock births" (Ferrara, 2013, para 8). Yet despite its incendiary title (“'Welfare State' Doesn't Adequately Describe How Much America's Poor Control Your Wallet") the article does nothing to connect spending on social welfare programs to the individuals wallets of Forbes' imagined audience. A review of several recent publications by the Heritage Foundation, a leading conservative think tank, reveals that for conservative thinkers, the success of a given welfare program or policy should be measured by its stinginess, and not by whether it helps the poor maintain a basic standard of living. For example, The Daily Signal's ${ }^{2}$ coverage of a TANF program extension in Colorado notes, "the [program] documents conceded the change could increase money going to welfare recipients and keep them on the program longer" (Kane, 2014, para 4). In the context of an anemic economic recovery that is concentrated in the upper socioeconomic classes, it would seem that an increase in benefits would be precisely the point of such a policy change. Similarly, articles by Edwin J. Feulner and by Robert Rector (2014) decry the dollar figures of welfare spending without ever considering the lived experiences of the poor. Human beings living in poverty are completely absent from the conversation about welfare, except when they are villainized and shamed.

Though it failed to pass, in late 2014 Congress considered an amendment to the Farm Bill requiring food surveillance in the Supplement Nutrition Assistance Program (SNAP). The legislation would have "mandated that retail food stores collect, and report to the Secretary of Agriculture, detailed information that identifies food items purchased with benefits provided under the supplemental nutrition assistance program" (Rogers, 2014). It is not at all clear what the amendment's sponsors thought should be done with this information, but the logic behind such a proposal is exactly what the commenter on Eubanks' article spelled out: welfare benefits are funded with tax dollars, which come from individual (as well as corporate) taxpayers, ergo said taxpayers have a right to know and control what welfare recipients purchase. This is the same logic that Hobby Lobby and its supporters used in Burwell vs. Hobby Lobby Stores, Inc. to successfully argue that at least some corporations should be exempt from the Affordable Care Act's requirement that health insurance plans cover birth control at no additional cost (beyond the insurance premium itself). Financial contribution, no matter how indirect, is construed as a source of legitimacy for controlling women's bodies. Poor women, by definition, lack the financial resources to combat

\footnotetext{
${ }^{2} \mathrm{~A}$ "national network of investigative reporters covering waste, fraud and abuse in government" affiliated with the Franklin Center for Government \& Public Integrity. The Heritage Foundation's website prominently links to The Daily Signal, signaling the outfit's ideological affiliation.
} 
these claims, whereas wealthier women are exempt from this control, as they tend to have better health insurance coverage or can afford to pay out-of-pocket. Yet we seldom hear serious arguments from pacifists that they should be able to veto defense expenditures because they pay taxes, or from scientists who refuse to pay for public school systems that teach Creationism, for example. There seems to be a cultural link between conservative thought and the belief that financially contributing to something, no matter how indirectly, creates a right to control distant outcomes.

\section{Analysis}

Welfare offices at every level of government spend exorbitant sums cross-referencing databases, following up on tips from welfare fraud hotlines, drug-testing, physically surveilling, and legally prosecuting the poor, ostensibly to save the taxpayer money by cutting off welfare frauds and cheaters. In many jurisdictions, the amount spent on welfare enforcement dwarves the sums saved by removing "cheaters" from welfare rolls. For example, the state of Utah spent $\$ 30,000$ over the course of a year to ferret out presumed drug use among welfare recipients. The program found that only $2.6 \%$ tested positive for illegal drugs, which is well below the national use rate, $8.9 \%$ (Kelly, 2013). Programs in Arizona, Oklahoma and Florida similarly failed at their purported goal of saving taxpayer money. In fact, the Florida program cost the state $\$ 45,780$ in testing expenditures (Alvarez, 2012).

One might think that this money would be better spent on welfare itself, especially in the context of the Great Recession and anemic recovery. However, a large body of social science research suggests that the guiding logic of the U.S. welfare system is not the actual wellbeing of poor families, but punishing the poor for being poor and setting them up as cautionary examples to discourage others from being poor as well (Bussiere, 1997; Gustafson, 2011; Eubanks, 2012; Piven \& Cloward, 1993; Gilliom, 2001; O'Connor, 2003; Seccombe, 2011; Soss, 2002). As Salon's Brian P. Kelly put it,

Welfare-based drug testing is only a symptom of a larger societal ill that sees the poor as inherently parasitic and viceful (e.g., "They take advantage of government programs, not us." "They do drugs, not us."). As a result, legislators heap unfair, ineffective policies on those in poverty simply to court public favor by playing to their prejudices. The welfare queen, cashing government checks, smoking drugs and living the life of luxury, continues to be a useful myth when it comes to winning votes. And as more of these policies, whose support is borne by an unfounded disdain for the poor, are enacted, the humanity of those living in poverty is further eroded as the chasm between the haves and the have-nots grows even wider. (Kelly, 2013)
Indeed, for Gustafson, "the drug testing of welfare recipients particularly highlights the conflation of poverty and crime and the widespread assumption that poor women of color are the causes of crime" (Gustafson, 2011, p. 60). While it seems that awareness of the limited usefulness of drug testing is relatively widespread in policy circles, the systematic surveillance of welfare recipients is either ignored or uncontroversial.

While mass drug testing seeks to control the risk that is presumably caused by poor women's bodies, electronic surveillance situates the assumed risk in the practices of everyday life, not least of which include poor women's sexual and reproductive lives. As more and more of daily life is captured by electronic databases whose data can be matched and analyzed in increasingly revealing ways, more facets of the human condition become susceptible to surveillance (Bauman \& Lyon, 2013). Electronic surveillance of the poor is particularly insidious for three reasons. First, welfare recipients who lack formal education and computer skills often have trouble conceiving of the types of data and computational analysis that are possible. Second, they lack the political capital to fight the system, much less change it, particularly as many welfare recipients have so internalized the trope of the "Welfare Queen" that they profess to believe that the system and its rules are necessary and just, even as they themselves "cheat" the system in whatever ways necessary to survive and provide for their families (Gilliom, 2001; Gustafson, 2011).

And finally, in the United States the receipt of most kinds of public assistance is highly stigmatized (with the important exception of maximizing tax deductions, which is widely applauded), and there is widespread support for all kinds of government intrusion in the lives of the poor: unannounced home visits, mandatory drug testing, electronic and physical surveillance, and family benefit caps intended to discourage women who receive welfare from giving birth to additional children. For example, the third comment on the online version of Eubanks' New Prospect article contains multiple assertions that "As a taxpayer I applaud looking at EBT records to see if you are spending MY money on WHAT I approve of, as in MY money" (Eubanks, 2014, online comments). This quote is representative of widespread cultural beliefs, as I discussed in the previous section.

\section{Conclusion}

This paper has tackled the systematic surveillance of Americans by foregrounding the well-entrenched practice of surveilling the poorest and most vulnerable members of society: welfare recipients. This practice is, outside of certain activist and academic circles, utterly uncontroversial and enjoys wide public support, even as other kinds of surveillance are coming under scrutiny. Writing in 2008, Henman and Marston noted that "the 
social policy literature seems to have taken a limited interest in recent developments in surveillance practices" (Henman \& Marston, 2008, p. 188) and that "academic interest in the social division of welfare has waned in recent years" (Henman \& Marston, 2008, p. 191).

While the academic and legal literature on this topic is very rich and conservative think tanks are prolific on the perils of welfare spending, the issue appears to be all but ignored in progressive public policy circles, even as they focus attention and resources on the mass surveillance programs that Edward Snowden exposed. I found only one reference to welfare surveillance among recent think tank policy papers, a collection of essays on "Big Data and Discrimination" published by New America (Peña Gangadharan, 2014). The digital rights sector doesn't perform much better: for example, the Electronic Privacy Information Center (EPIC) website has a page dedicated to "Poverty and Privacy," but it doesn't refer to any materials published since 2003. I have, however, been privy to confidential conversations and strategy meetings of civil society researchers and activists about the surveillance to which communities of color, including welfare recipients, are subjected. It remains to be seen what will come of these projects. Professional advocacy organizations tend to pick battles that they think they can win, and so far there is no indication that fighting for the civil rights and human dignity of welfare recipients is a winning political tactic. Updated research in the vein of Piven and Cloward's excellent "Poor People's Movements" (1979) is needed if poor Americans are to regain their dignity and humanity. Encouragingly, the aforementioned Virginia Eubanks is currently working on a book about welfare surveillance.

The paucity of the policy-oriented literature may very well be due to the absence of data, as the decentralized structure of welfare administration since 1996 makes it all but impossible to come by nationally comparable datasets on the welfare population or benefit levels. Because welfare programs are administered by the states on a county-by-county basis, the federal government has little to no authority to oversee or critically assess the adequacy of benefit levels, bureaucratic processes, or the return on investment in terms of assuring a decent quality of life for the poorest among us. For example, the statistics maintained by the Department of Health and Human Services (HHS) measure expenditures and the number of beneficiaries; no effort is made to account for how well welfare programs meet recipients' basic needs, or how well the programs are administered. In fact, states measure the success of their welfare programs by the number of needy Americans they can remove from the welfare rolls, regardless of what happens to these families afterward.

As discussed previously, welfare policy is plagued by the inaccurate beliefs that many Americans hold about public assistance beneficiaries. Speaking at a
2015 symposium organized by the University of Southern California Law School, Kaaryn Gustafson went so far as to say that we have "no chance" of living in a society where everyone (notably poor mothers) is treated with dignity and humanity until we dispense with the "Welfare Queen" trope. In turn, correcting these misperceptions is hindered by the information and data flows concerning welfare and its beneficiaries. The official statistics on welfare and poverty measure the wrong things in the wrong way, thereby creating nonfactual "knowledge" that hides genuine problems (hunger, poverty) while surfacing imaginary ones (illegitimacy, drug abuse, fraud, etc.).

Rather than measuring the prevalence of poverty and its human costs, federal statistics focus on the administration of the programs. For example, the Tenth TANF Annual Report to Congress noted that in 2011 (the most recent year for which this report is available), the Federal poverty threshold for a family of four (two adults plus two children) was $\$ 22,811$, that $21.9 \%$ of children were living in poverty that year (16.1 million), and that the child poverty rate in 2011 was 5.7 percentage points higher than in 2000. However, the report does not mention whether TANF (or other welfare programs) was successful in reducing the number of American children (much less adults) living in poverty, or the percentage of need that is met. Even the report's authors seem to be aware of the limitations of their data, noting:

\section{Participation of Eligible Families}

While many see TANF's caseload decline as a measure of the success of welfare reform, the sharp decline in participation among eligible families also raises concerns about its effectiveness as a safety net program. HHS uses an Urban Institute model to estimate the percentage of families eligible for assistance under state rules that are actually receiving TANF assistance.

As shown in Figure 2-E, and Appendix Table 2:3, this participation rate data shows that the share of eligible families receiving TANF declined from 84 percent in 1995 to 32 percent in 2009. (Tenth TANF Report to Congress, 2013, p. 21)

From these figures, it should be possible to compare benefits awarded against the need they are intended to ameliorate, yet this is not done. The closest that the report comes is Figure 9B, "Income Poverty Gap for All Families with Children 1997-2011" (p. 54). The poverty gap refers to the amount of money that would be required to raise all poor families to the poverty line. However, the figures are only provided with respect to families with children-demonstrating a lack of concern for adults living in poverty-and are not broken down by state or by any other category. The figures convey the fact that in 2011, it would have cost $\$ 76.5$ 
billion to raise all American children out of poverty, but stops short of providing any information that would help achieve this.

The report also highlights the low rates of participation of TANF-eligible families, yet it does not provide any additional information on possible reasons why less than a third of families that are eligible for TANF are not receiving benefits, stating:

In FY 1994, the assistance caseload reached a high of an average monthly 5.05 million families; six years later, the assistance caseload declined to an average monthly 2.36 million families in FY 2000. This decline has been attributed to a host of events, including economic growth (and the concomitant drop in poverty), welfare reform implementation, and other policies designed to promote work among low-income families with children (such as expansions in the Earned Income Tax Credit and child care subsidies). Throughout this period, there was a dramatic increase in the number of single mothers leaving TANF for work. (Tenth TANF Report to Congress, 2013, p. 15).

The last sentence clearly refers to the myth of Welfare Queen-still very much a concern for bureaucrats and elected officials alike. The reference to "welfare reform implementation" is a blatant tautology: welfare reform tightened eligibility requirements, and as a result fewer people were eligible for benefits-hardly the same thing as eliminating or even reducing poverty.

The example of federal statistics concerning TANF illustrate the broader reality that assessments of welfare programs emphasize inputs such as expenditures, ignoring program outputs and other measures of human wellbeing. From a public administration perspective this makes sense: the Department of Health and Human Services is legally mandated to collect and report these statistics. The question remains why it does not also provide measures of human wellbeing.

Moreover, the fact that a practice is legally mandated provides an explanation for why it exists, but does not constitute a moral or ethical reason. As with many other situations (legal protections for whistleblowers come to mind), the United States and postmodern societies more broadly lack a mechanism for reconciling the gap between what is legal and what is ethically or morally just.

The information that is most crucially lacking in the current data flows concerning welfare fall under three categories: the extent of need, how much of that need is met by the social safety net, and cost/benefit analyses of fraud prevention. The fact that so many members of the wealthiest society in human history are needy is reprehensible, and welfare programs ought to be evaluated by their success in meeting that need. Granular datasets and tables that examine these two types of measures by state, county, and various demographic dimensions would shed light on outcome disparities between different groups, thus allowing for targeted remedies. Finally, the effectiveness of fraudprevention schemes should be methodically assessed. Schemes that cost more than the amount saved should be eliminated, and the funding reinvested into benefit payments. For example, in 2009 the California State Auditor found that "the measurable savings resulting from early fraud detection activities exceed the costs of such efforts for CalWORKs and approach cost neutrality for the food stamp program" (Howle, 2009). By this logic, then, early fraud detection was a valuable investment for CalWORKS, but not for food stamps. More state and local level auditors and Inspectors General should pursue this kind of analysis and pressure the agencies that administer welfare programs to do the same.

It is vitally important that researchers in academia, in government, and in civil society do the work of generating accurate, nationally comparable empirical evidence to inform policy and debate. Indeed, the lack of data is a key barrier to both research and advocacy. Even as the system relentlessly seeks out every scrap of information about the poor to verify their deservingness, it deliberately fails to provide systemic data that would help administer programs more effectively. This is a stunning paradox: a system whose guiding principle is the collection of information yields virtually no data that could meaningfully inform public policy.

To the lay person the argument that welfare surveillance robs the poor of their dignity and humanity may seem like wild hyperbole. But as Gilliom reminds us,

Surveillance programs are ways of seeing and knowing the world. They assert values, identify priorities, define possibilities, and police the departures. In so doing, they build important structures of meaning that help to shape our world and our place within it (Gilliom, 2001, p. xiii).

Welfare surveillance is also a feminist issue. As I have discussed, surveillance of welfare recipients is overwhelmingly concerned with the sexual and reproductive lives of poor women, as reflected by practices such as bed checks, family size caps, and home visits designed to catch women living with an unrelated male. Additionally, poor women-and increasingly, working class women-are denied access to birth control, then shamed and punished for becoming pregnant. As abortion care becomes increasingly restricted, the message sent to poor women is a simple choice: marriage or abstinence. Meanwhile, poor men are largely excluded from receiving aid since most welfare programs are designed to support children (and by association their caregivers, albeit begrudgingly). The main mechanism through which poor men are expected to interact with 
the welfare system is through child support collections.

Popular opposition to welfare is deeply rooted in the historical legacy of racism (Gordon, 1994; Quadagno, 1994). Indeed, opposition to the social safety net is connected to the (inaccurate) belief that welfare recipients are overwhelmingly black (Gilens, 1999). Surveillance of any kind is "not a mere glance exchanged between equals - it is both an expression and instrument of power" (Gilliom, 2001, p. 3). By exercising their right to surveil and control the daily lives of poor Americans via the state, self-proclaimed "taxpayers" assert their position of privilege over the poor and mark them as Other.

Nor is welfare distinct from the plight of low-wage workers in a neoliberal society. Under the transatlantic leadership of Reagan and Thatcher, the 1980s saw "an assault on organized labor, initially the trade unions, but extending to collectivist ideas tout court" (Webster, 2014 , p. 85)-including the notion of a social safety net. This trend has only accelerated over the past 30 years. As companies increasingly automate low-skilled work and outsource jobs to cheaper labor markets, the share of the U.S. workforce that is contingent (i.e. cycling between employment and unemployment) has been growing steadily, reaching up to $25 \%$ of the labor market (Webster, 2014, p. 89). The most vulnerable among these are discursively excluded from society, and are instead constructed as an underclass "thought to inhabit the inner city ghettoes and isolated parts of the regions, but significantly it is considered a tiny group detached from the vast majority of society, separate and self-perpetuating, which, if an irritant to lawabiding, is apart from the bulk of the populace, which is mortgage-owning, self- and career-centered" (Webster, 2014, p. 89). As a result, the poor, left "without a stake in post-industrial society...are to be pitied, feared and condemned (Dalrymple, 2005; Mount, 2010)" (Webster, 2014, p. 90).

While it is true that the poor's standard of living is higher today than it was in the industrial era, the poor have been increasingly marginalized relative to the middle and upper classes. Webster (2014) notes that "while in the past the working class was subordinate to the owners of capital, it was widely accepted that it was still indispensable" (Webster, 2014, p. 123). Today, with much of American manufacturing and blue-collar jobs having been outsourced to countries with lower labor costs (and often lesser or non-existent regulatory protections for labor), it is much easier for the middle and upper classes to dismiss the poor as a distant "Other" whose struggles are theoretically troubling, but practically irrelevant. This is why I propose to change the data inputs into the cybernetic machine of the welfare state (Wiener, 1988). Only when the state, and the bureaucrats who comprise it, start measuring success by human impact factors rather than economic measures of thrift will meaningful policy change be possible. Civil society should lead the way by producing these datasets to the extent possible, perhaps by focusing on a specific state or local jurisdiction, then confronting relevant public sector actors about the relative inadequacy of their own data. The California State Auditor's report is an encouraging example of what can be accomplished.

In this paper I have alluded to the surveillance society's shifting gaze as one group after another has become targeted for surveillance. The function of surveillance is to monitor and isolate the risk that each group is deemed to present to society: welfare recipients, African Americans, civil rights activists, Arab and Muslim Americans, journalists, individual police officers, and more. In addition to direct state surveillance, 21st century Americans are also subject to commercial and social surveillance through social networking sites, which often provide the mechanism for state surveillance (Angwin, 2014; Scheer, 2015). Much like the proverbial frog who is boiled to death because he fails to realize that the water is getting warmer, we as a societyAmericans in particular, but not exclusively-are in danger of waking up in a Panopticon of our own creation.

\section{Acknowledgements}

The author wishes to thank the following individuals for their comments on early versions of this article: Manuel Castells, Cat Duffy, Henry Jenkins, and Andrew Shrock.

\section{Conflict of Interests}

The author declares no conflict of interests.

\section{References}

Alvarez, L. (2012, April 17). No savings found in Florida welfare drug tests. The New York Times. Retrieved from http://www.nytimes.com/2012/04/18/us/nosavings-found-in-florida-welfare-drug-tests.html

Angwin, J. (2014). Dragnet nation: A quest for privacy, security, and freedom in a world of relentless surveillance (First edition). New York: Times Books, Henry Holt and Company.

Bauman, Z., \& Lyon, D. (2013). Liquid surveillance: A conversation. Cambridge, UK, Malden, MA: Polity Press.

Beck, U. (1992). Risk society: Towards a new modernity. London, Newbury Park, CA: Sage Publications.

Beutler, B. (2014, September 30). Mitt Romney blames his "47 percent" comment on a donor. Paul Ryan blames...Mitt Romney. The New Republic. Retrieved from http://www.newrepublic.com/article/119645/ romney-47-percent-quote-was-donors-fault-paulryan-it-was-wrong

Bussiere, E. (1997). (Dis)entitling the poor: The Warren 
Court, welfare rights, and the American political tradition. University Park, PA: Pennsylvania State University Press.

Cofer, M. D. P. (1982). Administering public assistance: A constitutional and administrative perspective. Port Washington, NY: Kennikat Press.

Dalrymple, T. (2005). Our culture, what's left of it: The mandarins and the masses. Chicago: Ivan R. Dee.

Eubanks, V. (2012). Digital dead end: Fighting for social justice in the Information Age. Cambridge, MA, London: MIT Press.

Eubanks, V. (2014, January 15). Want to predict the future of surveillance? Ask poor communities. The American Prospect. Retrieved from http://prospect. org/article/want-predict-future-surveillance-askpoor-communities

Ferrara, P. (2013, June 23). "Welfare state" doesn't adequately describe how much America's poor control your wallet. Retrieved from http://www. forbes.com/sites/peterferrara/2013/06/23/welfare -state-doesnt-adequately-describe-how-muchamericas-poor-control-your-wallet

Giddens, A. (1987). The Nation-state and violence. Berkeley: University of California Press.

Gilens, M. (1999). Why Americans hate welfare: Race, media, and the politics of antipoverty policy. Chicago: University of Chicago Press.

Gilliom, J. (2001). Overseers of the poor: Surveillance, resistance, and the limits of privacy. Chicago: University of Chicago Press.

Glasmeier, A. K., \& Schulteis, E. (2015). Poverty in America: Living wage calculator (California). Boston, MA: Massachusetts Institute of Technology. Retrieved from http://livingwage.mit.edu/states/06

Glick, B. (1989). War at home: Covert action against U.S. activists and what we can do about it (1st ed.). Boston, MA: South End Press.

Gordon, L. (1994). Pitied but not entitled: Single mothers and the history of welfare. New York, NY: The Free Press.

Greenwald, G., \& Hussain, M. (2014, July 8). Meet the Muslim-American leaders the $\mathrm{FBI}$ and NSA have been spying on. The Intercept. Retrieved from https://firstlook.org/theintercept/2014/07/09/und er-surveillance

Gustafson, K. S. (2011). Cheating welfare: Public assistance and the criminalization of poverty. New York: New York University Press.

Hancock, A. M. (2004). The politics of disgust: The public identity of the welfare queen. New York: NYU Press.

Hasenfeld, Y. (2000). Organizational forms as moral practices: The case of welfare departments. Social Service Review, 74(3), 329-351.

Henman, P., \& Marston, G. (2008). The social division of welfare surveillance. Journal of Social Policy, 37(2), 187-205. doi:10.1017/s0047279407001705
Hillyard, P., \& Percy-Smith, J. (1988). The coercive state. London: Fontana.

Howle, E. M. (2009). Department of social services: for the CalWORKs and food stamp programs, it lacks assessments of cost-effectiveness and misses opportunities to improve counties' antifraud efforts (84 pp.). California State Auditor. Retrieved from https://www.bsa.ca.gov/pdfs/reports/2009-101.pdf

Kane, A. (2014, November 19). Colorado's new welfare rule increases benefits, costs taxpayers. Retrieved from http://dailysignal.com/2014/11/19/coloradosnew-welfare-rule-increases-benefits-coststaxpayers

Kaplan, R. (n.d.). John Boehner nixes unemployment insurance extension. Retrieved from http:// www.cbsnews.com/news/john-boehner-nixesunemployment-insurance-extension

Kelly, B. P. (2013). An inane, money-eating sham: Drug tests for welfare a huge failure. Retrieved from http://www.salon.com/2013/08/29/gop\%e2\%80\%9 9s_inane_money_eating_sham_drug_tests_for_wel fare_a_huge_failure

Landler, M. (2012, September 20). Obama hits Romney over 47 percent remark. The New York Times "The Caucus" Blog. Retrieved from http://thecaucus. blogs.nytimes.com/2012/09/20/obama-hits-backat-romney-on-47-percent-remark

Mink, G. (1996). The wages of motherhood: Inequality in the welfare state, 1917-1942. Cornell University Press.

Mount, F. (2010). Mind the gap 2010. London: Short.

Neubeck, K. J., \& Cazenave, N. A. (2001). Welfare racism: Playing the race card against America's poor. Psychology Press.

O'Connor, B. (2003). A political history of the American welfare system: Ehen ideas have consequences. Lanham, MD: Rowman \& Littlefield.

Office of Family Assistance, Administration for Children and Families, U.S. Department of Health and Human Services. (2013). Tenth TANF Report to Congress. Washington, DC. Retrieved from http:// www.acf.hhs.gov/programs/ofa/resource/tenthreport-to-congress

Peña Gangadharan, S. (2014). Data and Discrimination: Collected Essays. Washington, DC: New America. Retrieved from http://www.newamerica.org/down loads/OTI-Data-an-Discrimination-FINAL-small.pdf

Piven, F. F., \& Cloward, R. A. (1979). Poor people's movements: Why they succeed, how they fail (Vol. 697). New York: Vintage books.

Piven, F. F., \& Cloward, R. A. (1993). Regulating the poor: The functions of public welfare. New York: Vintage Books.

Quadagno J. (1994). The color of welfare: How racism undermined the war on poverty. New York, NY: Oxford University Press, 1994.

Rector, R. (2014, February). Help the poor by trans- 
forming, not growing, welfare. Retrieved from http://dailysignal.com/2014/02/01/help-poor-

transforming-growing-welfare

Roberts, D. E. (1996). Welfare and the problem of black citizenship (University of Pennsylvania Law School Faculty Scholarship Paper 1283). Retrieved from http://scholarship.law.upenn.edu/faculty_scholarsh ip/1283

Rogers, J. (2014, September 25). Food surveillance is not welfare reform. CapAllies Post. Retrieved from http://capallies.com/2014/09/food-surveillance-isnot-welfare-reform

Scheer, R. (2015). They know everything about you: How data-collecting corporations and snooping government agencies are destroying democracy.
New York: Nation Books.

Schram, S. (2000). After welfare: The culture of postindustrial social policy. NYU Press.

Seccombe, K. (2011). "So you think I drive a Cadillac?": Welfare recipients' perspectives on the system and its reform (3rd ed.). Boston, MA: Allyn \& Bacon.

Soss, J. (2002). Unwanted claims: The politics of participation in the U.S. welfare system. Ann Arbor: University of Michigan Press.

Webster, F. (2014). Theories of the information society (4th ed.). Abingdon, Oxon: Routledge.

Wiener, N. (1988). The human use of human beings: Cybernetics and society. New York, NY: Da Capo Press.

\section{About the Author}

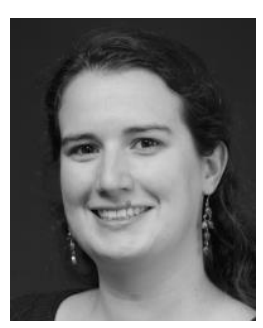

\section{Nathalie Maréchal}

Nathalie Maréchal is a PhD student in Communication at the University of Southern California. Her research interests include media and international relations, media history, international and comparative media, media ethics, technology and society, and cross-cultural communication, while her own work focuses on privacy, surveillance, human rights, activism, and the political economy of circumvention and anonymization technology. 